\section{Psychosocial stressors and support needs of survivors of Ebola virus disease, Bombali District, Sierra Leone, 2015}

\author{
Waheed Ariyo Bakare, ${ }^{1}$ \\ Olayinka Stephen Ilesanmi, ${ }^{2}$ \\ Edmund Presiror Nabena, ${ }^{3}$ \\ Temitope Famuyide ${ }^{4}$ \\ 'Nigeria Center for Disease Control, \\ Abuja; ${ }^{2}$ Department of Community \\ Health, Federal Medical Centre, Owo; \\ ${ }^{3}$ Braithwaite Memorial Specialist \\ Hospital, Port Harcourt, Nigeria; ${ }^{4}$ African \\ Union Support Ebola in West Africa, \\ Addis Ababa, Ethiopia
}

\section{Abstract}

Ebola virus disease (EVD) survivors are increasing. There is a need to document their psychosocial stressors and support needs to enable appropriate interventions. The aim of this study was to document psychosocial stressors and support needs of EVD survivors in Bombali District, Sierra Leone, in 2015. Qualitative and quantitative methods were used. A cross-sectional study design (questionnaire) was used for quantitative data collection from 299 survivors, while in-depth interview was done for 6 survivors. Parental losses, poor economic situation, joblessness, lack of food were among the problems reported. The median age of survivors was 24 years (range 189 years). Orphans were 66 (22.1\%), widows were 59 (19.7\%), while widowers were 19 (6.4\%). Food was needed by $291(97.3 \%)$ of the survivors, 196 (65.6\%) reported they needed clothing. Shelter was the need of $20(6.7 \%)$ survivors, while $246(82.3 \%)$ wanted financial support. In all, 4 (1.4\%) survivors were rejected by their families' members, while community members rejected another 4 (1.3\%). Ebola survivors are champions and they should be projected in that light within their family and community. Governments need to establish strategic partnership with non-governmental bodies to ensure the needs of the survivors are met.

\section{Introduction}

The outbreak of Ebola virus disease (EVD) in 2014 remained by far the largest and longest outbreak of viral hemorrhagic fever ever in the world. ${ }^{1}$ The spread of EVD is due to traditional, socio-cultural attitudes (funeral rites), eco- nomic and political issues and the insufficient supply of disposable infection, prevention and control (IPC) materials in the communities and hospitals. ${ }^{2}$ Ebola virus can be transmitted by close contact with body fluids of an infected person (who is symptomatic) or an infected corpse. Sierra Leone has recorded more than $50 \%$ of confirmed cases (over 12,000) in this outbreak and more than 3000 deaths. ${ }^{3}$

In August 2014, Ebola was reported in Sierra Leone during farming activities, and this rendered many farmers - including some Ebola survivors - inactive by restricting their movement and enclosing them in quarantine homes and communities. These resulted in damaged farm produce and food shortage. There was no opportunity to harvest or store farm produce. After the rain there was nothing to sell because the majority harvested nothing. Since the beginning of the 2014 EVD outbreak, more than 400 Ebola survivors have been recorded in Sierra Leone's Bombali district. ${ }^{4}$

There are few explanations to why patients go through psychosocial stresses after being discharged from Ebola treatment center (ETC). These factors include mental and physical health issues, how much they could count on others for support, personal and family history of mental health problems, cultural background, traditional practices, and age. ${ }^{5}$ Either one or a combination of these factors influenced the medical and mental responses of survivors to Ebola. These factors are also unique in the sense that each survivor bears varying degrees of how much he/she could withstand the impact of any of the factors. One major factor that assists any survivor in going through the psychological after-effects of Ebola is the availability of sustainable psychosocial support systems within the immediate family and the broader community they are integrated with. ${ }^{6}$

The most common psychological challenges faced by Ebola survivors include: sadness, fear, depression, frequent anxiety, panic, insomnia and nightmares, confusion, emotional numbness, embarrassment, low morale, lack of confidence, frustration, helplessness. ${ }^{2}$ These psychological effects are expressed in the outward disposition and display of survivors such as being of few words, low voice when they speak, withdrawn from people, conversation delays, over thinking, display of disregard to others, appearing lost and self-isolation and loss of hope. And there are explanations to these psychological experiences; when examined, it is realized that coming out of the ETC is a single stressor producing experience. Others include, family reaction when tested positive to the disease, bad experiences in holding centres, bad experiences with ambulances, excessive isolation in the red zone of the ETC and the shocking news of family members who have died unknown to them while they were undergoing
Correspondence: Olayinka Stephen Ilesanmi, Department of Community Health, Federal Medical Centre, Owo, Ondo State, Nigeria. Tel:+234.8032121868.

E-mail: ileolasteve@yahoo.co.uk

Key words: Ebola virus; Psychosocial stressors; Sierra Leone; Welfare.

Acknowledgements: volunteers of Africa Union Support to Ebola Outbreak in West Africa (ASEOWA), District Health Management Team (DHMT), and staff of the World Health Organization (WHO) Bombali District, Sierra Leone are thanked.

Received for publication: 2 July 2015 .

Revision received: 31 August 2015.

Accepted for publication: 31 August 2015.

This work is licensed under a Creative Commons Attribution 3.0 License (by-nc 3.0).

(C) Copyright W.A. Bakare et al., 2015

Licensee PAGEPress, Italy

Healthcare in Low-resource Settings 2015; 3:5411 doi:10.4081/hls.2015.5411

treatment in the ETC. Some studies have examined the general health needs of EVD survivors. ${ }^{7-9}$ There is a need to document psychosocial stressors and support needs of EVD survivors to enable appropriate interventions. This study aimed to document psychosocial stressors and support needs of EVD survivors in Bombali district, Sierra Leone.

\section{Materials and Methods}

The study was conducted at Bombali district of Sierra Leone. Bombali is the second largest district in Sierra Leone based on geographical land mass (after Koinadugu district) and the second most populous district in the North, after Port Loko district. Before Ebola in 2014, the population of Sierra Leone was over 6 million. ${ }^{10}$ Agricultural sector (food and tree crops, fishery, livestock and forestry) is the backbone of the economy in the country. The raining season is between May and October.

A mixed method comprising of qualitative and quantitative methods was used for this study. A cross-sectional study design was used for quantitative data collection, while in-depth interview was used for the qualitative aspect. Survivors in Bombali district were invited to a survivor's conference organized by the District Health Management Team (DHMT) Bombali District, African Union, WHO, UNICEF and other partners. In all, 310 survivors attended the conference out of which 299 participated fully by responding to interviewer adminis- 
tered questionnaire used for data collection. The survivors' conference was held in Kamaranka village to favor those outside the city and in Makeni city in February 2015.

\section{Qualitative aspect}

This study was conducted among EVD survivors. A survivor is a person who had suffered Ebola as confirmed by a positive Ebola polymerase chain reaction (PCR) or serology tests, went through the Ebola disease management and survived the disease. The survivor status is confirmed when the patient tests negative to an Ebola PCR test after EVD management. Saturation of ideas was achieved after interviewing 6 survivors. In-depth responses about the psychosocial experiences were obtained. Few verbatim quotations were included.

\section{Procedure}

Invitation was given to the participants during a meeting. Participation of survivors was voluntary. All participants were advised that they could withdraw from the study at any time. No one refused to participate and nonwithdrew their participation from this study. Questions were asked about the psychosocial needs of the survivors. Questions were unstructured and designed to promote openended responses. Interview was between 15-20 minutes. An observer who could write fast wrote the responses. This assured complete capturing of responses. The study participants were informed that their responses would help in improving the psychosocial health of EVD survivors. The psychosocial needs identified in the qualitative data collection complemented the quantitative data. The data was collected in February 2015.

\section{Quantitative aspect}

Informed consent was sought and obtained from the survivors. Clinically oriented psychosocial welfare officers interviewed the respondents individually using a standardized questionnaire written in English. The questionnaire has two parts, the first part comprised of sociodemographic characteristics while the second was on their psychosocial needs. Identical questions were asked from all survivors irrespective of tribe, religion or ETC where they were managed. Interpreters were used to aid the understanding of those who could not speak English.

\section{Data management}

Questionnaires were checked for omissions and errors. Corrections were made where necessary to the questionnaires. Data was analyzed with Microsoft excel. Only descriptive statistics was done.

\section{Ethical considerations}

This study was based on data collected during surveillance and response activities for
EVD in Sierra Leone. All information collected on individual survivors was anonymous to improve their state of health.

\section{Results}

\section{Qualitative results}

With regard to family stress, the first interviewee said that her husband had 3 wives with 14 children while her husband's younger brother had two wives with eight children. There were 22 children in the family. The whole family comprising of adults and children (29 in all) were together in the same compound before EVD affected them. Only the woman and nine children were left behind as survivors. They depended on well-wishers for their daily needs, she added. The post Ebola economic challenge was huge. The country's economic situation was unfavorable to many. Free movements, inter-trade between towns and cities and normal market conditions ceased following the Ebola outbreak. This situation has been linked to extreme poverty, unemployment and food shortage in the country.

A 12-year-old girl narrated her experiences. She and her two younger brothers were orphaned by EVD. They reside in Robuyya village, Bombali District. The first brother was 3 years, while the second was 7 months. She solicited for food from the community for 6 months (since October 2014) to take care of her brothers. How she was able to care for a 7-month-old brother from age 2 months was surprising.

Another respondent lost 12 persons out of her family members to Ebola. She would be 19 years in November 2015. This girl who was an orphan was also a student in one of the secondary schools in Bo. The mother who got the EVD from her elderly son infected her with the disease before the rest of the family contracted it. She was the only survivor among her family members. Due to lack of financial support she could not join her colleagues when schools reopened.

A 35-year-old man who was admitted on the $6^{\text {th }}$ November 2014 at the Hastings ETC in Freetown got the Ebola virus during his rescue mission to help his people in November 2014. He is knowledgeable about the use of PPE and also trained others, but this did not prevent him from contracting the virus. I tried my best but it has been destined that I would get it. I saved many lives but I lost many of my family members to this deadly disease. I reported myself early but still, my 2 brothers, 3 children and wife died. My remaining 3 children survived but no money to take care of them, he added.

A 19-year-old survivor orphaned by EVD a resident of Masongbo village also narrated her story. Me Papa, me mama die in October. My problem now be me eye. Me eye no see and I no get nothing. Ar no get money, Ar no get job. E for better make Ar die. She spoke in Krio Language. She was a secondary school student who was infected in January, 2015 by her survivor boyfriend that was discharged from the ETC in December 2014. She was treated and discharged in January from Mateneh ETC. When school reopened she could not resume due to both financial issues and stigma.

A nurse was also interviewed. He was the only survivor in a family of 10 . His wife, 5 children, his 2 younger brothers and mother died. He started crying during the interview and he said I don't even know where to start. He was reassured, offered some relief materials and the interview was terminated.

A young man was discharged on $11^{\text {th }}$ December, 2014. He collected survivors' package from the ETC, which comprises of a bag of rice, some condiments, mattress, bucket and a sac bag which contained condoms, flip-flops, blanket and some clothes. The clothes he was giving were feminine; he could not use any of it. He added that before he arrived home from the ETC where he was treated all his belongings were burnt by the decontamination team.

\section{Quantitative results}

Among the 299 respondents who participated in this study, male were 117 (39.1\%). The median age of survivors was 24 years (range 189 years). Respondents aged 18 years and above were $204(60.2 \%)$. Orphans were 66 (22.1\%), widows were 59 (19.7\%) while widowers were 19 (6.4\%) (Table 1).

Table 2 shows the support needs of EVD survivors in Bombali district Sierra Leone. Food was needed by 291 (97.3\%) of the survivors, $196(65.6 \%)$ reported they needed clothing. Shelter was the need of 20 (6.7\%), while 246 $(82.3 \%)$ wanted financial support. About 144 (48.2\%) were willing to learn new vocations.

Table 3 shows the psychological stressors encountered by EVD survivors in Bombali district. Inability to access property was reported by $10(3.3 \%)$ survivors. They were not privileged to go back to their property such as houses and farm after they survived and returned home. In all, 4 (1.4\%) survivors were rejected by their families' members, while community members rejected another 4 (1.3\%). Since the time the survivors were discharged from the ETC, $106(35.4 \%)$ were not able to return to their job or do their businesses.

\section{Discussion}

This study aimed to document psychosocial stressors and support needs of EVD survivors in Bombali District, Sierra Leone, using quali- 
tative and quantitative (mixed) methods.

More than half of the studied population are female and also adults. Every one out of five was an orphan and also every one in five was a widow. Economic problem was common to orphans after the deaths of parents; orphans were faced with loss of household income. The problem of how to pay treatment costs was reported by those who developed post Ebola health issues. Most of these orphans were seen with dirty, faded and/or old cloth. Orphans were easily dispossessed of their inheritance

Table 1. Sociodemographic characteristics of survivors of Ebola virus disease, Bombali district, Sierra Leone, 2015.

\begin{tabular}{lcc} 
Sociodemographic characteristics & Frequency & Percent \\
Sex & & \\
$\quad$ Male & 117 & 39.1 \\
$\quad$ Female & 182 & 60.9 \\
Age group (years) & & \\
$\quad<18$ & 95 & 31.8 \\
$\quad \geq 18$ & 204 & 60.2 \\
\hline Marital status & & \\
$\quad$ Single/married & 155 & 51.8 \\
$\quad$ Widows & 59 & 19.7 \\
$\quad$ Widowers & 19 & 6.4 \\
Orphans & 66 & 22.1 \\
\hline
\end{tabular}

Table 2. Support needs of survivors of Ebola virus disease, Bombali district, Sierra Leone, 2015.

\begin{tabular}{lcc} 
Support needs & Frequency & Percent \\
Food & & \\
Yes & 291 & 97.3 \\
No & 8 & 2.7 \\
Clothing & & \\
Yes & 196 & 65.6 \\
No & 103 & 34.4 \\
\hline Shelter & & \\
Yes & 20 & 6.7 \\
No & 279 & 93.3 \\
Financial support & & \\
Yes & 246 & 82.3 \\
No & 53 & 17.7 \\
\hline Vocational needs & & \\
Yes & 144 & 48.2 \\
No & 155 & 51.8 \\
\hline
\end{tabular}

Table 3. Psychological stressors encountered by survivors of Ebola virus disease, Bombali district, Sierra Leone, 2015.

\begin{tabular}{lcc} 
Stressors & Frequency & Percent \\
Inability to access property & & \\
$\quad$ Yes & 10 & 3.3 \\
$\quad$ No & 289 & 96.7 \\
Family rejection & 4 & 1.3 \\
$\quad$ Yes & 295 & 98.7 \\
$\quad$ No & & \\
Community rejection & 4 & 1.3 \\
$\quad$ Yes & 295 & 98.7 \\
$\quad$ No & & \\
Job loss & 106 & 35.4 \\
Yes & 193 & 64.6 \\
No & & \\
\hline
\end{tabular}

when the parents died this increased the economic problems that were already established on them. ${ }^{11}$ The severity of the economic or financial challenges facing survivors determined all other problem.

There was variance in the way survivors were coping with life after Ebola. Some of these could be traced to how EVD was communicated in their local community and the level of their own understanding of the disease. It did not help when Ebola is surrounded by mythological beliefs such as the virus is a weapon of witch craft, giving an impression that anyone infected must have offended the gods. Ebola was portrayed as a self-induced punishment for a wrongdoing an individual had committed. Feeling of guilt conscience, indifference to getting treatment from an ETC or delay in doing so and lack of any form of hope in chances of surviving the disease might be a contributory factor for not reporting early.

Ebola affected all the socio-economic activities in the affected countries. This added to the problems of survivors. The opportunity to trade was not available with lock down of movements here and there. Kudos to Government of Sierra Leone and also the Ministry of Social Welfare, Gender and Children Affairs for making sure that survivors got what was called survivors package at the point of their exit from the ETCs. The packages vary though based on the treatment centre but the fact was that the government and some partners were there to give the survivors some essential emergency needed including money following discharge from the ETC.

The social challenges facing Ebola survivors were numerous and these generally fell within food, shelter, finance, education and health services. These needs also vary based on the classes of survivors such as orphans, widows/widowers, divorced, aged and children.

\section{Conclusions}

Discussions are on to know the issues facing the survivors after discharge from the ETC. There is need for haste in converting these discussions into tangible interventions. A comprehensive approach must include proper integration of survivors into the community. We have heard of survivors rejected by their communities on the grounds that they were witches. It is unacceptable for a person to survive a disease as deadly as Ebola only to die from poverty, frustration from hunger or lack of job. Therefore, the government in conjunction with implementing partners must help these survivors to restart their lives.

A holistic approach for addressing psychological challenges of survivors should include a focused psychological first aid to help survivors 
understanding their conditions and reverse negative assumptions they probably hold in mind. An aggressive community behavioral change communication must be put in place to inform and guide communities and family members on the significance of surviving Ebola and the peculiar psychological support they require to help rebuild their lives to normality, particularly addressing the issues of stigmatization. ${ }^{12,13}$ Ebola survivors are champions and they should be projected in that light within the family and community. Effective health education/communication would help to identify the needs of the survivors. ${ }^{6}$ Governments need to establish more strategic partnership with non-governmental bodies in the area of treatment, research and welfare.

\section{References}

1. Centers for Disease Control and Prevention. 2014 Ebola outbreak in West Africa. Available from: http://www.cdc.gov/vhf/ebola/outbreaks/20 14-west-africa/
2. Umeora 0, Emma-Echiegu N, Umeora MNA. Ebola viral disease in Nigeria: the panic and cultural threat. Afr J Med Health Sci 2014;13:1-5.

3. Saeidi M, Moghadam HT, Kiani MA, et al. A short overview of ebola outbreak. Int $\mathrm{J}$ Pediatrics 2014;2:287-94.

4. National Ebola Response Centre. NERC 2015. Available from: http://nerc.s//

5. The World Bank. The socio economic impact of Ebola in Sierra Leone 2015. Available from: http://www.worldbank.org /en/topic/poverty/publication/socio-economic-impacts-ebola-sierra-leone

6. Davtyan M, Brown B, Folayan M. Addressing Ebola-related stigma: lessons learned from HIV/AIDS. Global Health Action 2014;7:26058.

7. Bausch DG. Sequelae after Ebola virus disease: even when it's over it's not over. Lancet Infect Dis 2015;15:865-6.

8. Medical Xpress. Study examines long-term adverse health effects of Ebola survivors 2015. Available from: http://medicalxpress.com/news/2015-04-long-termadverse-health-effects-ebola.html

9. Clark DV, Kibuuka H, Millard M, et al.
Long-term sequelae after Ebola virus disease in Bundibugyo, Uganda: a retrospective cohort study. Lancet Infect Dis 2015;15:905-12

10. Countrymeters. Sierra Leone population 2015. Available from: http://countrymeters.info/en/Sierra_Leone

11. Steinberg M, Johnson S, Schierhout G, Ndegwa D. Hitting home: how households cope with the impact of the HIV/AIDS epidemic: a survey of households affected by HIV/AIDS in South Africa. Menlo Park, CA: Kaiser Family Foundation; 2002. Available from: http://www.ceped.org/cgi /wwwisis. cgi/\%5Bin=../cdrom/orphelins_sida_2006/ en/biblio/direct.in\%5D/?t2000=124X/\%285 $\% 29$

12. McLeroy KR, Norton BL, Kegler MC, et al. Community-based interventions. American J of Public Health 2003;93:52933.

13. Start Fund. Is sensitisation effective in changing behaviour to prevent Ebola transmission? Available from: http://www. start-network.org/wp-content/uploads/ 2014/09/Start-Fund-SLE-case-study.pdf 